\title{
Lipid-Reducing Effects of Sulphate-Sulphide Mineral Water in Patients With Knee Osteoarthritis
}

\author{
Tatjana Erceg-Rukavina, ${ }^{1}$ Dragana Dragičević-Cvjetković1, 2
}

\section{Abstract}

Background / Aim: The positive effect of thermal mineral waters on human health has been known for a long time. Many pathophysiological mechanisms of action of balneotherapy are not specified. Patients with gonarthrosis often have elevated values of serum lipids. This study aimed to examine the effect of drinking sulphate-sulphide thermo mineral water on the lipid status of patients with gonarthrosis.

Methods: A prospective clinical study followed 60 patients, both sexes, mean age $65.02 \pm 1.03$, with gonarthrosis. All inpatient underwent physical treatment with topical application of sulphate-sulphide mineral water. Patients of group A $(\mathrm{N}=30)$ had the use of this mineral water as an additional therapy by drinking, unlike patients of group B $(\mathrm{N}=30)$ who drank plain water. The level of serum lipids of these patients was monitored at admission and 4 weeks after. The variance analysis test (ANOVA) with a level of statistical significance $\mathrm{p}<0.001$ was used for statistical analysis.

Results: A significant reduction in the levels of all lipid fractions in the serum of patients with gonarthrosis was found 4 weeks after the completion of inpatient physical treatment in both study groups. This decrease was statistically significant in patients of group A $(\mathrm{p}<0.001)$.

Conclusion: Drinking sulphate-sulphide mineral water in patients with gonarthrosis shows a positive effect on the reduction of serum lipid levels in the short-term follow-up period.

Key words: Balneotherapy; Serum; Lipids; Osteoarthritis; Knee.
(1) Institute of Physical Medicine and Rehabilitation "Dr Miroslav Zotović", Banja Luka, the Republic of Srpska, Bosnia and Herzegovina.

(2) Faculty of Medicine, University of Banja Luka, the Republic of Srpska, Bosnia and Herzegovina.

Correspondence:

TATJANA ERCEG-RUKAVINA

E: dr.tanjaerceg@gmail.com M: +387 65737936

\section{ARTICLE INFO}

Received: 5 December 2021 Revision received: 7 December 2021 Accepted: 7 December 2021

\section{Introduction}

Osteoarthritis $(\mathrm{OA})$ is the most common joint disease and one of the main causes of pain and disability. It is a mildly progressive, degenerative and chronic disease that occurs as a result of joint cartilage damage. There is growing evidence that OA is also a "metabolic disorder" associated with insulin resistance, abdominal obesity, high cholesterol, high blood pressure and coagulation disorders. ${ }^{1-3}$ The level of total fatty acids and arachidonic acid within chondrocytes noticeably increases with severe cartilage damage. ${ }^{4}$ In addition, the expression of genes that regulate cho- lesterol uptake into chondrocytes of damaged cartilage is reduced, which also contributes to lipid deposition. ${ }^{5}$ Some studies have linked elevated blood lipids and osteoarthritic changes. ${ }^{6}$ The use of bicarbonate and sulphate-sulphide mineral water by drinking under controlled conditions could lower blood lipid levels. ${ }^{7-9}$ The exact mechanism of antilipemic action of these mineral waters is unknown. The increase in bile acid excretion is related to the alkaline nature of mineral waters and the osmotic effect. The release of pancreatic enzymes and bile acids increases with

Copyright @ 2021 Erceg-Rukavina and Dragičević-Cvjetkovicl. This is an open access article distributed under the Creative Commons Attribution License (CC BY), which permits unrestricted use, distribution, and reproduction in any medium, provided the original work is properly cited. This article should be cited as follows: Erceg-Rukavina T, Dragičević-Cvjetković D. Lipid-reducing effects of sulphate-sulphide mineral water in patients with knee osteoarthritis. Scr Med 2021 Dec;52(4):294-8. 
increasing $\mathrm{pH}$ under the influence of mineral water, which leads to reduced uptake of cholesterol in the small intestine and its increased excretion in the faeces. The loss of bile acids through faeces is increased which could stimulate the liver to produce more bile acids from cholesterol. Consequently, the number of hepatic LDL cholesterol receptors increases, leading to a decrease in serum LDL cholesterol. ${ }^{10}$ This study aimed to examine the effect of internal application (drinking) of sulphide-sulphate mineral water on the lipid status of patients with gonarthrosis.

\section{Methods}

The study was conducted as an open, controlled, prospective study of 60 patients with gonarthrosis at the Hospital for Physical Medicine and Rehabilitation "Mlječanica" in Kozarska Dubica. All respondents gave their voluntary consent to participate in the trial and signed informed consent. The Ethics Committee of the "Mlječanica" Hospital has approved this study. The microbiological correctness of the mineral drinking water was confirmed by the PHI Institute of Public Health Banja Luka No M-3206-V-4-2015 (Table 1). ${ }^{11}$ Criteria for inclusion in the study were knee pain most days of the previous month and radiological confirmation of knee osteoarthritis. The study non-inclusion criteria were: significant changes in blood pressure, cardiac arrhythmias, cardiac decompensation, neurological disorders, complications of the gastrointestinal tract (vomiting, diarrhoea, abdominal cramps) and personal reasons of the subjects. The sample was divided into two groups (group A and group B) of 30 respondents each. All patients were given balneo-physical treatment every day, six days a week (the seventh day is a break from treatment) for the 4 weeks. The total of 24 treatments included: transcutaneous electrical nerve stimulation (TENS) on the affected knee exercises to increase the range of motion in the knee and strengthen the quadriceps and hamstrings and locally applied baths of sulphate-sulphide mineral water temperature $31-33^{\circ} \mathrm{C}$ for 20 minutes. Subjects from group A drank $100 \mathrm{~mL}$ of sulphate-sulphide mineral water three times a day, just before meals and patients from group B drank three times $100 \mathrm{~mL}$ of plain tap water three times a day before meals. The outcome was evaluated on the first and 28th day of rehabilitation. The following serum laboratory parameters were measured on each subject: to-
Table 1: Physical-chemical analysis of sulphurous mineral water "Mlječanica"

\begin{tabular}{|c|c|c|c|c|c|}
\hline Compound & & $\mathrm{mg} / \mathrm{L}$ & $\mathrm{mmol} / \mathrm{L}$ & $\mathrm{m} / \mathrm{val} / \mathrm{L}$ & m. val $\%$ \\
\hline \multirow[t]{4}{*}{ Anions } & Hydrocarbon & 577.06 & 9.460 & 9.460 & 18 \\
\hline & Chloride & 15.80 & 0.440 & 0.440 & 1 \\
\hline & Sulfate & 2840.00 & 21.250 & 42.500 & 81 \\
\hline & Phosphate & 0.01 & 0.000 & 0.000 & 0 \\
\hline \multicolumn{6}{|c|}{ Total mineralisation (mg/L) 2932.87} \\
\hline \multirow[t]{6}{*}{ Cations } & Sodium & 165.00 & 7.174 & 7.174 & 14 \\
\hline & Potassium & 7.20 & 0.185 & 0.185 & 0 \\
\hline & Calcium & 436.86 & 10.900 & 21.800 & 41 \\
\hline & Magnesium & 257.79 & 10.600 & 21.200 & 40 \\
\hline & Strontium & 11.20 & 0.127 & 0.225 & 1 \\
\hline & Ammonium & 35.00 & 2 & 1.940 & 4 \\
\hline
\end{tabular}

Total mineralisation (mg/L) 913.06; m. val: mineral value

tal cholesterol, triglycerides, HDL cholesterol and LDL-cholesterol. The concentration of total cholesterol and triglycerides in the serum was determined by standard enzymatic methods with the help of commercial tests from the company Human. The concentration of HDL-cholesterol was determined in the supernatant after precipitation of all other lipoproteins with the help of a precipitating agent for the semi-micro method PREC-b and the concentration of LDL-cholesterol by the precipitation method. The variance analysis test (ANOVA) with a level of $p<0.001$ was considered statistically significant.

\section{Results}

A total of 60 patients (19 males and 41 females, mean age $65.02 \pm 1.03$ ) participated in the study, 30 in each group. Both groups were homogenous regarding age, gender and affected knee (Table 2).

Table 2: Demographic characteristics of the subjects

\begin{tabular}{lcc}
\hline Group & Group A & Group B \\
\hline No of subjects & 30 & 30 \\
\hline Mean age & 65.70 & 66.50 \\
\hdashline Sex & $\mathrm{M}=9 ; \mathrm{F}=21$ & $\mathrm{M}=10 ; \mathrm{F}=20$ \\
\hline Comorbidities & 22 & \\
\hline Hypertension & 3 & $24{ }^{*} \mathrm{*} \mathrm{p}=0.542$ \\
\hline Varicose veins & $\mathrm{L}=16 ; \mathrm{R}=14$ & $4{ }^{*} \mathrm{*}=1.000$ \\
\hline Affected knee & $\mathrm{L}=18 ; \mathrm{R}=12$ \\
\hline *Fisher test: $p>0.05 ; M=$ male; $F=$ female; $L=$ left; $R=$ right;
\end{tabular}

Decrease of serum lipids had obtained in patients in both groups. This decrease was statistically significant in patients in group A (treated with sulphate-sulphide mineral water) $\mathrm{p}<0.001$ (Table 3 ). 
Table 3: Differences in serum lipid values in patients of groups $A$ and $B$ (admission/discharge)

\begin{tabular}{|c|c|c|c|c|c|c|c|}
\hline \multirow{2}{*}{ Lipid values } & \multirow{2}{*}{$\begin{array}{l}\text { Treatment } \\
\text { (water) }\end{array}$} & \multicolumn{5}{|c|}{ Water } & \multirow{2}{*}{ p value } \\
\hline & & Mean & SD & Median & Perc. 25 & Perc. 75 & \\
\hline \multirow{2}{*}{ Total cholesterol (admission) } & regular & 7.01 & 1.11 & 6.75 & 6.12 & 7.97 & \multirow{2}{*}{$0.700^{\mathrm{a}}$} \\
\hline & mineral & 6.91 & 0.85 & 6.74 & 6.54 & 7.26 & \\
\hline \multirow{2}{*}{ Total cholesterol (discharge) } & regular & 6.00 & 0.87 & 5.91 & 5.43 & 6.43 & \multirow{2}{*}{$<0.001^{\mathrm{a}}$} \\
\hline & mineral & 5.20 & 0.62 & 5.30 & 4.80 & 5.80 & \\
\hline \multirow{2}{*}{$\Delta$ Total cholestrol } & regular & -1.01 & 1.02 & -0.71 & -1.77 & -0.27 & \multirow{2}{*}{$0.001^{\mathrm{a}}$} \\
\hline & mineral & -1.70 & 1.02 & -1.80 & -2.35 & -0.71 & \\
\hline \multirow{2}{*}{ Triglycerides (admission) } & regular & 2.67 & 1.33 & 2.76 & 1.82 & 2.97 & \multirow{2}{*}{0.539} \\
\hline & mineral & 2.84 & 1.21 & 2.52 & 1.97 & 3.30 & \\
\hline \multirow{2}{*}{ Triglycerides (discharge) } & regular & 2.41 & 1.13 & 2.37 & 1.74 & 2.72 & \multirow{2}{*}{$0.007^{b}$} \\
\hline & mineral & 1.80 & 0.88 & 1.77 & 1.50 & 1.98 & \\
\hline \multirow{2}{*}{$\Delta$ Triglycerides } & regular & -0.27 & 0.85 & -0.19 & -0.40 & 0.06 & \multirow{2}{*}{$<0.001^{b}$} \\
\hline & mineral & -1.04 & 0.91 & -1.04 & -1.51 & -0.27 & \\
\hline \multirow{2}{*}{ HDL (admission) } & regular & 1.43 & 0.60 & 1.37 & 1.02 & 1.78 & \multirow{2}{*}{$0.703^{\mathrm{a}}$} \\
\hline & mineral & 1.49 & 0.67 & 1.29 & 1.00 & 1.85 & \\
\hline \multirow{2}{*}{ HDL (discharge) } & regular & 1.47 & 0.60 & 1.34 & 1.02 & 1.89 & \multirow{2}{*}{$0.005^{\mathrm{a}}$} \\
\hline & mineral & 1.94 & 0.64 & 1.90 & 1.40 & 2.45 & \\
\hline \multirow{2}{*}{$\Delta \mathrm{HDL}$} & regular & 0.04 & 0.37 & 0.04 & -0.07 & 0.20 & \multirow{2}{*}{$0.001^{\mathrm{a}}$} \\
\hline & mineral & 0.45 & 0.53 & 0.28 & 0.05 & 0.90 & \\
\hline \multirow{2}{*}{ LDL (admission) } & regular & 5.21 & 1.28 & 5.22 & 4.00 & 6.20 & \multirow{2}{*}{$0.228^{a}$} \\
\hline & mineral & 4.83 & 1.18 & 4.53 & 3.70 & 5.71 & \\
\hline \multirow{2}{*}{ LDL (discharge) } & regular & 4.55 & 0.96 & 4.22 & 3.80 & 5.00 & \multirow{2}{*}{$<0.001^{\mathrm{a}}$} \\
\hline & mineral & 3.56 & 0.48 & 3.52 & 3.10 & 3.91 & \\
\hline \multirow{2}{*}{$\Delta \mathrm{LDL}$} & regular & -0.66 & 1.08 & -0.32 & -0.98 & -0.01 & \multirow{2}{*}{0.028} \\
\hline & mineral & -1.26 & 1.00 & -1.15 & -2.13 & -0.32 & \\
\hline
\end{tabular}

a - $T$ test for independent samples; $b$ - Mann Whitney U test; red colour: statistical significance; perc: percentile;

\section{Discussion}

At first glance, patients with gonarthrosis would not be closely associated with elevated serum lipids. However, these patients are mostly older, less physically active and adipose, the connection of these clinical entities can be seen. Patients from both study groups had elevated serum lipid fractions at baseline. There are studies showing lipid deposition within damaged cartilage. The expression of genes that regulate the intake of cholesterol in chondrocytes is reduced, which in turn contributes to increased lipid deposition in chondrocytes. ${ }^{5}$ In a 2009 study of 148 middle-aged women without clinical signs of gonarthrosis and with reference cholesterol and triglyceride values, Davies et al found an increased number of women with osteoarthritis who had low and elevated serum lipids after two years. ${ }^{6}$ The treatment of patients with dyslipidaemias is complex and requires a multidisciplinary approach. Physiological treatment of patients with gonarthrosis can affect the level of reduction of serum lipids in several ways. One is the reduction of body weight, the other is the increase of physical activity through training, but the effect of balneotherapy is not reduced. ${ }^{12-15}$ The mechanisms of action of sulphate-sulphide mineral waters on the level of serum lipids have been insufficiently investigated. The mechanisms that could explain this effect are increased excretion of bile acids and pancreatic enzymes, alkalinity of mineral waters and osmotic effect. Cholesterol uptake in the small intestine is reduced and its excretion is increased. This leads to a decrease in the liver's cholesterol reserve which withdraws LDL cholesterol from the serum and thus leads to its reduction. ${ }^{16}$

Positive effects of sulphate-sulphide mineral water have been found in patients with constipation and gastritis. ${ }^{17}$ Positive effects of local application of these mineral waters have also been reported in patients with hypertension and after cerebrovascular insult. ${ }^{18-20}$

Our research can undoubtedly be considered pioneering because no research has been done so far on the impact of mineral water in patients with dyslipidaemia. Balneotherapy as a cheap and affordable therapy could, if its positive effects are proven, be a significant modality of non-pharmacological treatment of these patients. 
The results obtained in this study need to be interpreted from several angles. Namely, the effect of mineral water on BMI was not examined due to a short follow-up period of 4 weeks. The effect of drug therapy was minimised because all patients due to pain took only Paracetamol in a maximum dose of $3 \mathrm{~g}$ per day due to knee pain. Patients in the study groups did not receive statin therapy.

As all patients were on a reduction diet during all 28 days, the effect of the diet was reduced to a minimum. Therefore, a significant decrease in serum lipids in patients in group A can only be attributed to the effect of drinking sulphate-sulphide mineral water. However, a short follow-up period and a small sample are the disadvantages of this study.

\section{Conclusion}

Drinking sulphate-sulphide mineral water leads to a decrease in serum lipids in patients with gonarthrosis in the short-term follow-up period.

\section{Acknowledgements}

None.

\section{Conflict of interest}

None.

\section{References}

1. Velasquez MT, Katz JD. Osteoarthritis: another component of metabolic syndrome? Metab Syndr Relat Disord 2010 Aug;8(4):295-305.

2. Yoshimura N, Muraki S, Oka H, Tanaka S, Kawaguchi H, Nakamura K, et al. Accumulation of metabolic risk factors such as overweight, hypertension, dyslipidaemia and impaired glucose tolerance raises the risk of occurrence and progression of knee osteoarthritis: a 3-year follow-up of the ROAD study. Osteoarthritis Cartilage 2012 Nov;20(11):1217-26.

3. Leite AA, Costa AJ, Lima Bde A, Padilha AV, Albuquerque $\mathrm{EC}$, Marques $\mathrm{CD}$. Comorbidities in patients with osteoarthritis: frequency and impact on pain and physical function. Rev Bras Reumatol 2011 MarApr;51(2):118-23.

4. Lippiello L, Walsh T, Fienhold M. The association of lipid abnormalities with tissue pathology in human osteoarthritic articular cartilage. Metabolism 1991 Jun;40(6):571-6.

5. Tsezou A, Iliopoulos D, Malizos KN, Simopoulou T. Impaired expression of genes regulating cholesterol efflux in human osteoarthritic chondrocytes. J Orthop Res 2010 Aug;28(8):1033-9.

6. Davies-Tuck ML, Hanna F, Davis SR, Bell RJ, Davison SL, Wluka AE, et al. Total cholesterol and triglycerides are associated with the development of new bone marrow lesions in asymptomatic middle-aged women - a prospective cohort study. Arthritis Res Ther 2009;11(6):R181. doi: 10.1186/ar2873.

7. Goszcz A, Kostka-Trabka E, Grodzińska L, Sławiński M, Bieroń K, Jachym R, et al. [The effect of treatment with sulphur water from the spring in Wiesław in Busko-Solec on levels of lipids, the fibrinolytic system and thrombogenic platelet function in patients with arteriosclerosis]. Pol Merkur Lekarski 1997 Jul;3(13):33-6. Polish.

8. Aslanabadi N, Habibi Asl B, Bakhshalizadeh B, Ghaderi F, Nemati M. Hypolipidemic activity of a natural mineral water rich in calcium, magnesium and bicarbonate in hyperlipidemic adults. Adv Pharm Bull 2014;4(3):303-7.

9. Perez-Granados MA, Navas-Carretero S, Schoppen S, Pilar M. Reduction of cardiovascular risk by sodium-bicarbonate mineral water in moderately hypercholesterolemic young adults. J Nutr Biochem 2010;21(10):948-53.

10. Rideout TC, Harding SV, Jones PJ, Fan MZ. Guar gum and similar soluble fibers in the regulation of cholesterol metabolism: current understandings and future research priorities. Vasc Health Risk Manag 2008;4(5):1023-33.

11. Stefanovski G, Erceg-Rukavina T, Stefanovksi M. Effects of balneotherapy on an affected upper limb after stroke. In: Abstract Book.18th European Congress of Physical and Rehabilitation Medicine 2012; p:81-83.

12. Christensen R, Astrup A, Bliddal H. Weight loss: the treatment of choice for knee osteoarthritis? A randomized trial. Osteoarthritis Cartilage 2005 Jan;13(1):20-7.

13. Christensen R, Bartels EM, Astrup A, Bliddal H. Effect of weight reduction in obese patients diagnosed with knee osteoarthritis: a systematic review and meta-analysis. Ann Rheum Dis 2007 Apr;66(4):433-9.

14. Fransen M, Crosbie J, Edmonds J. Physical therapy is effective for patients with osteoarthritis of the knee: a randomized controlled clinical trial. J Rheumatol 2001 Jan;28(1):156-64.

15. Deyle GD, Allison SC, Matekel RL, Ryder MG, Stang JM, Gohdes DD, et al. Physical therapy treatment effectiveness for osteoarthritis of the knee: a randomized comparison of supervised clinical exercise and manual therapy procedures versus a home exercise program. Phys Ther 2005 Dec;85(12):1301-17.

16. Capurso A, Solfrizzi V, Panza F, Mastroianni F, Torres F, Del Parigi A, et al. Increased bile acid excretion and reduction of serum cholesterol after crenotherapy with salt-rich mineral water. Aging (Milano) 1999 Aug;11(4):273-6.

17. Tišma R, Stefanovski G, Stefanovski M. Natural healing sulfur water of the Institute "Mlječanica". 1st ed. Laktaši, Bosnia and Herzegovina: Grafomark, 2005. 
18. Erceg-Rukavina T, Stefanovski M. Effects of Sulphate-Sulphide mineral water "Mlječanica" in Patients with Hypertension. Mater Sociomed 2014 Dec;26(6):364-65.

19. Stefanovski G. Balneotherapy with sulphate-sulphide mineral water in the rehabilitation of patients after stroke. Dissertation. Belgrade, Serbia: University of Belgrade, 1999.

20. Erceg-Rukavina T. Effects of balneotherapy in shoulder rehabilitation after stroke. Master's thesis. Banja Luka, Bosnia and Herzegovina: University of Banja Luka, 2012. 